\title{
SMARTPHONE ADDICTION DITINJAU DARI SUBJECTIVE WELL BEING, KECEMASAN SOSIAL, DAN MATERIALISME PADA MAHASISWA
}

\section{SMARTPHONE ADDICTION OBSERVED FORM SUBJECTIVE WELL BEING, SOCIAL ANXIETY, AND MATERIALISME AMONG COLLEGE STUDENTS}

\section{Submited : \\ 5 Februari 2019 \\ Revision : \\ 12 Maret 2019}

Accepted :

24 Juni 2019
Oleh:

Rahmah Saniatuzzulfa ${ }^{1}$

Alifa Nur Wijiyanti

\begin{abstract}
The purpose of this study was to look at subjective well being, social anxiety, and materialism with smartphone addiction. The research subjects were 361 students. The method of data collection uses the scale of smartphone addiction $(\alpha=0.873)$, subjective well being scale $(\alpha=0.925)$, social anxiety scale $(\alpha=0.956)$, and scale of materialism $(\alpha=0.881)$. Data analysis using multiple linear regression analysis which produces a value of $p=0,000(p<0.05)$ with a value of Fcount> Ftable $(18.757>2.70)$. This means that there is a relationship between subjective well being, social anxiety, and materialism with smartphone addiction. The value of $r 2$ is 0.365 , indicating that subjective well being, social anxiety, and materialism make an effective contribution of $36.5 \%$ in smartphone addiction.

Keywords: social anxiety, materialism, smartphone addiction, subjective well being
\end{abstract}

\begin{abstract}
ABSTRAK
Tujuan penelitian ini adalah melihat hubungan subjective well being, kecemasan sosial, dan materialisme dengan smartphone addiction pada mahasiswa universitas "Y". Subjek penelitian berjumlah 361 mahasiswa. Metode penggumpulan data menggunakan skala smartphone addiction $(\alpha=$ $0,873)$, skala subjective well being $(\alpha=0,925)$, skala kecemasan sosial $(\alpha=0,956)$, dan skala materialisme $(\alpha=0,881)$. Analisis data menggunakan analisis regresi linier berganda yang menghasilkan nilai $\mathrm{p}=0,000(\mathrm{p}<0,05)$ dengan nilai Fhitung $>$ Ftabel $(18.757>2,70)$. Artinya terdapat hubungan antara subjective well being, kecemasan sosial, dan materialisme dengan smartphone addiction pada mahasiswa universitas "Y". Nilai $\mathrm{r}^{2}$ sebesar 0,365, menunjukkan bahwa subjective well being, kecemasan sosial, dan materialisme memberikan sumbangan efektif sebesar 36,5\% pada smartphone addiction.
\end{abstract}

Kata Kunci: kecemasan sosial, materialisme, smartphone addiction, subjective well being

\section{PENDAHULUAN}

Perkembangan teknologi yang semakin pesat melahirkan berbagai inovasi baru, salah satunya adalah munculnya smartphone dengan berbagai fitur menarik yang terus dikembangkan setiap harinya. Kemudahan dalam mengakses berbagai informasi hanya dalam satu ganggaman tangan, membuat masyarakat tidak dapat terlepas dari smartphone ini.

\footnotetext{
${ }^{1}$ Rahmah Saniatuzzulfa, Program Studi Psikologi Fakultas Kedokteran Universitas Sebelas Maret, Email : rsaniatuzzulfa@gmail.com

${ }^{2}$ Alifa Nur Wijiyanti, Rumah Sakit Universitas Sebelas Maret Surakarta
} 
RAHMAH SANIATUZZULFA \& ALIFA NUR WIJAYANTI, Smartphone Addiction

Ditinjau dari Subjective Well Being, Kecemasan Sosial, dan Materialisme Pada Mahasiswa

Smartphone menjadi kebutuhan mendasar pada semua kalangan usia di seluruh dunia saat ini (Samaha dan Hawi, 2016). Sifatnya yang mudah digunakan, mudah dibawa, dan mudah disimpan memuat seseorang merasa diuntungkan dengan kehadiran teknologi ini (Spacz, Rockman, dan Clark, 2016; Cha \& Seo, 2018; Yao dan Zhong, 2014).

Berdasarkan data yang diperoleh dari APJII (2017) menunjukkan jumlah pengguna dengan 1 unit smartphone mencapai 95,75\%, pengguna dengan 2 unit sebanyak 3,69\%, 3 unit sebanyak $0,48 \%$ dan $0,08 \%$ pengguna dengan lebih dari 3 unit smartphone. Konten yang paling disering diakses antara lain media sosial, hiburan, berita, pendidikan, komersial, dan layanan publik.

Dari berbagai manfaat yang diperoleh dari smartphone ini, ternyata menimbulkan juga banyak dampak negatif pada penggunaan smartphone yang di luar kontrol yang dapat mengganggu kehidupan sehati-hari. Hal ini dapat dikatakan dengan smartphone addiction (Kwon, Lee, Won, Park, Min, Hahn, \& Kim., 2013a; Kwon, Kim, Cho, \& Yang, 2013b; Lee, Ahn, Choi, \& Choi, 2014). Ditambahkan oleh Roberts, Pullig, dan Manolis (2016) bahwa smartphone addiction sebagai ketidakmampuan seseorang untuk berkonsentrasi pada tugas yang dipegangnya.

Hasil survei yang dilakukan peneliti pada 196 mahasiswa, menunjukkan lama penggunaan smartphone lebih dari 5 jam, kurangnya kemampuan mahasiswa dalam mengontrol penggunaan smartphone, merasa mendapat kenyamanan ketika berkomunikasi dalam dunia maya, smartphone menjadi salah satu hal penting bagi kehidupannya. Yuwanto (2010), menyebutkan terdapat empat faktor yang menyebabkan seseorang mengalami smartphone addiction, yaitu faktor internal, situasional, sosial, dan eksternal.

Seseorang yang puas dengan kehidupannya akan bahagia karena mampu menyesuaikan dirinya dengan lingkungan keluarga, pekerjaan, dan masyarakat (Kumalasari \& Ahyani, 2012) sehingga ia mampu mengendalikan dirinya, termasuk dalam mengendalikan penggunaan smartphone. Ia dapat memilih waktu yang tepat untuk menggunakan smartphone (Kumcagiz \& Gunduz, 2016).

Salah satu cara yang dilakukan seseorang dalam berkomunikasi untuk menyembunyikan kecemasan sosial dengan media smartphone karena hal ini dianggap dapat mengurangi intimidasi dari orang lain (Lee, Chang, Cheng \& Lin, 2016). Hasil penelitian Lee, Chang, Lin, dan Cheng (2014); Spacz, Rockman dan Clark (2016) serta Darcin, Kose, Noyan, Nurmedov, Yilmaz, \& Dilbaz. (2016) menunjukkan hubungan signifikan antara kecemasan sosial dengan smartphone addiction.

Smartphone seringkali dijadikan tolok ukur status ekonomi seseorang (Aljomaa, Al Qudah, Albursan, Bakhiet, \& Abduljabbar, 2016). Bagi orang materialisme, smartphone menjadi salah satu harta yang berharga (Roberts, Pullig, \& Manolis, 2015). Penggunaan smartphone ini tidak hanya didasarkan pada fungsinya saja, melainkan lebih kepada kepuasan serta mengikuti tren (Lee, Chang, Lin, \& Cheng 2014). Hal ini diperkuat oleh penelitian yang menujukkan hubungan signifikan antara materialisme dan smartphone addiction (Roberts dan Pirog, 2013).

Pengertian smartphone addiction menurut Kwon, Kim, Cho, dan Yang (2013a) serta Kwon, dkk. (2013b) adalah penggunaan berlebihan pada smartphone, yang dapat membuat kehidupan sehari-hari seseorang menjadi terganggu. Aspek-aspek smartphone addiction menurut Kwon, Kim, Cho, dan Yang (2013a) serta Kwon, dkk. (2013b) meliputi gangguan sehari-hari, positive anticipation, menarik diri, cyberspace-oriented relationship, penggunaan berlebihan, dan toleransi.

Subjective well being menurut Diener, Oisho, dan Lucas (2003) adalah kebahagiaan secara keseluruhan yang dialami individu, di mana individu memiliki perasaan yang positif atas hidupnya sebagai hasil evaluasi afektif dan memiliki kepuasan hidup atas apa yang dicapai baik secara global maupun mengenai domain-domain hidup tertentu sebagai hasil evaluasi 
kognitif. Lebih lanjut, Diener, Oisho, dan Lucas (2003) menjabarkan komponen subjective well being ke dalam empat komponen, yaitu kepuasan hidup/life satisfaction, kepuasan atas ranahranah tertentu/domain satisfaction, afek positif/positive affect, dan afek negatif/negative affect.

Mattick dan Clarke (1998) menjelaskan definisi kecemasan sosial secara umum yakni kesulitan yang dirasakan seseorang ketika orang lain memperhatikan atau mengamati diri seseorang yang membuat individu tidak nyaman untuk melakukan aktivitas dan cenderung menghindari situasi tersebut yang berisi tentang Aspek-aspek kecemasan sosial milik Mattick dan Clarke (1998) meliputi pengamatan oleh orang lain, ketakutan jika orang lain memperhatikan gejala kecemasan, serta memulai dan memperhatikan interaksi sosial.

Materialisme diartikan oleh Richins dan Dawson (1992) serta Richins (2004) sebagai nilai seseorang dalam melihat lingkungan dan kehidupan diri sendiri yang akan mempengaruhi cara menginterpretasikan mengenai hal tersebut. Richins dan Dawson (1992) serta Richins (2004) menyampaikan tiga aspek dari materialisme, yaitu sukses, sentralitas, dan kebahagiaan.

\section{METODE PENELITIAN}

Populasi yang digunakan dalam penelitian ini adalah mahasiswa universitas "Y" yang terdaftar pada tahun akademik 2017/2018 yang tersebar di sepuluh fakultas. Teknik pengambilan sampel yang digunakan dalam penelitian ini, yaitu disproportionatecluster randomsampling. Penelitian ini mengambil enam fakultas dari sepuluh fakultas di Universitas "Y". Sampel dalam penelitian ini berjumlah 361 orang.

Penelitian ini menggunakan empat macam skala sebagai alat ukur untuk memperoleh data yang diperlukan yaitu skala smartphone addiction, skala subjective well being, skala kecemasan sosial, dan skala materialisme yang diberikan secara langsung pada subjek penelitian.

Smartphone addiction pada penelitian ini diukur menggunakan skala smartphone addiction berdasarkan aspek yang sudah dikemukakan oleh Kwon, Kim, Cho, dan Yang (2013a) serta Kwon, dkk. (2013b) meliputi gangguan sehari-hari, positive anticipation, menarik diri, cyberspace-oriented relationship, penggunaan berlebihan, dan toleransi. Hasil uji-coba menunjukkan bahwa dari 34 aitem terdapat 24 aitem valid pada rentang 0,280 sampai dengan 0,682 , dengan koefisien reliabilitas $(\alpha)=0,873$.

Subjective well being pada penelitian ini diukur menggunakan skala yang disusun berdasarkan aspek subjective well being milik Diener, Oisho, dan Lucas (2003) yaitu kepuasan hidup/life satisfaction, kepuasan atas ranah-ranah tertentu/domain satisfaction, afek positif/positive affect, dan afek negatif/negative affect. Hasil uji-coba menunjukkan bahwa dari 39 aitem terdapat 26 aitem valid pada rentang 0,339 hingga 0,676 , dengan koefisien reliabilitas $(\alpha)=0,925$.

Kecemasan sosial dalam penelitian ini diukur menggunakan modifikasi dari skala yang disusun oleh Mattick dan Clarke (1998), yang tersusun berdasarkan aspek pengamatan oleh orang lain, ketakutan jika orang lain memperhatikan gejala kecemasan, serta memulai dan memperhatikan interaksi sosial. Hasil uji-coba menunjukkan bahwa dari 33 aitem terdapat 31 aitem valid pada rentang 0,390 sampai 0,844, dengan koefisien reliabilitas $(\alpha)=0.956$.

Materialisme pada penelitian ini diukur menggunakan skala materialisme berasal dari modifikasi dari skala Richins dan Dawson (1992) serta Richins (2004). Aspek-aspek dalam skala penelitian ini sesuai dengan aspek yang terdapat pada skala Richins dan Dawson (1992) serta Richins (2004), meliputi sukses, sentralitas, dan kebahagiaan. Hasil uji-coba menunjukkan bahwa dari 28 aitem terdapat 21 aitem valid pada rentang 0,314 hingga 0,654, dengan koefisien reliabilitas $(\alpha)=0,881$. 
RAHMAH SANIATUZZULFA \& ALIFA NUR WIJAYANTI, Smartphone Addiction

Ditinjau dari Subjective Well Being, Kecemasan Sosial, dan Materialisme Pada Mahasiswa

Penelitian ini merupakan studi analisis regresi linear berganda dengan 4 prediktor. Sehingga dilakukan uji prasyarat yaitu uji asumsi dasar dan uji asumsi klasik. Perhitungan analisis data menggunakan program Statistical Product and Service Solution (SPSS) Versi 17.0.

\section{HASIL DAN PEMBAHASAN}

UjI asumsi dasar meliputi uji normalitas dan uji linearitas. Berdasarkan hasil uji normalitas pada skala smartphone addiction, subjective well being, kecemasan sosial dan materialisme menggunakan One-Sample Kolmogrov- Smirnov Test masing-masing yaitu dengan nilai $\mathrm{p}>0,05$, maka dapat disimpulkan data keempat variabel terdistribusi secara normal.

Hasil uji linearitas menunjukkan kolom linearity nilai signifikansi 0,000 untuk smartphone addiction dan kecemasan sosial, nilai signifikansi 0,000 untuk smartphone adiiction dan materialisme, serta nilai signifikansi untuk smartphone adiiction dan subjective well-being sebesar 0,000. Oleh karena itu, dapat dikatakan terdapat hubungan linear antara keempat variabel.

Uji asumsi klasik meliputi uji multikolinearitas, uji heteroskedastisitas dan uji autokolerasi. Hasil uji multikolinearitas antar variabel prediktor (subjective well being, kecemasan sosial, dan materialisme) yaitu nilai Variance Inflation Factor (VIF) secara berurutan $=1,358$; dan Tolerance $=0,737$. Berdasarkan hasil tersebut menunjukkan bahwa nilai VIF $<5$ dan Tolerance $\geq 0,10$ sehingga dapat disimpulkan bahwa antar variabel predikor tidak terjadi multikolinearitas.

Hasil uji heteroskedastisitas menunjukkan bahwa titik-titik data menyebar secara tidak beraturan dan tidak berpola. Hal ini menunjukkan model regresi bebas dari asumsi heteroskedatisitas.

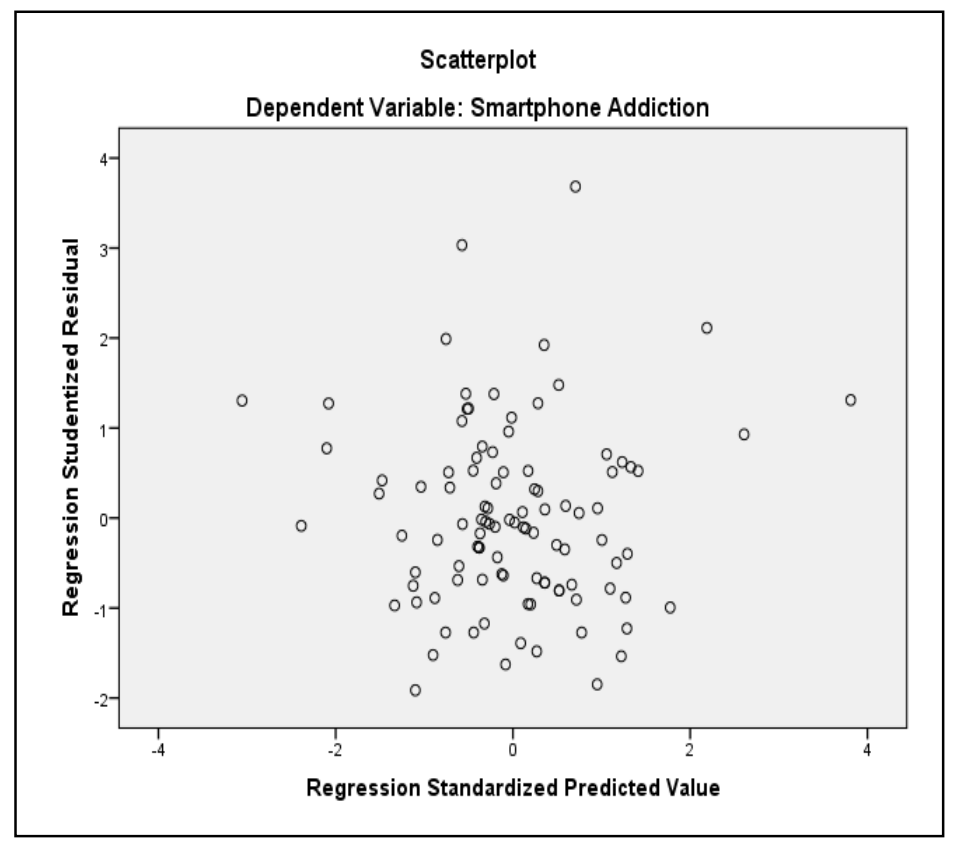

Gambar 1. Hasil Uji Heteroskedastisitas

Hasil uji autokolerasi menunjukkan nilai DW sebesar 1,824. Nilai DW berada diantara $-2<1,824<2$. Hasil tersebut menunjukkan bahwa penelitian ini tidak terjadi autokorelasi.

Sementara hasil Uji Hipotesis digambarkan pada table 1 di bawah ini : 
Tabel 1.

Uji Simultan (F)

ANOVA $^{\mathrm{a}}$

\begin{tabular}{|ll|r|r|r|r|r|}
\hline Model & & Sum of Squares & df & Mean Square & F & Sig. \\
\hline 1 & Regression & 1766.431 & 3 & 588.810 & 18.757 & $.000^{\mathrm{b}}$ \\
& Residual & 3076.442 & 98 & 31.392 & & \\
& Total & 4842.873 & 101 & & & \\
\hline
\end{tabular}

a. Dependent Variable: Smartphone Addiction

b. Predictors: (Constant), Subjective Well-Being, Materialisme, KecemasanSosial

Tabel di atas menunjukkan bahwa nilai signifikasi ( $p$-value) pada kolom Sig. sebesar $0,001(\mathrm{p}<0,05)$ serta diketahui bahwa nilai $F_{\text {hitung }}$ sebesar 18,757 dan besar nilai $F_{\text {tabel }} 2,70$ sehingga hipotesis pertama dalam penelitian ini diterima. Maka dapat disimpulkan bahwa subjective well being, kecemasan sosial, dan materialisme secara bersama berpengaruh signifikan terhadap smartphone addiction.

Uji hipotesis 2, 3, dan 4 menggunakan uji hipotesis korelasi pearson. Uji hipotesis 2, 3, dan 4 untuk mengetahui hubungan salah satu variabel prediktor dengan variabel kriterium.

Tabel 2.

Hasil Uji Korelasi Pearson

Correlations

\begin{tabular}{|c|c|c|c|c|c|}
\hline & & Smartphone Addiction & KecemasanSosial & Materialisme & $\begin{array}{l}\text { Subjective } \\
\text { Well-Being }\end{array}$ \\
\hline \multirow[t]{3}{*}{$\begin{array}{l}\text { Smartphone } \\
\text { Addiction }\end{array}$} & $\begin{array}{l}\text { Pearson } \\
\text { Correlation }\end{array}$ & 1 & $.380^{* *}$ & $.511^{* *}$ & $-.429^{* *}$ \\
\hline & Sig. (2-tailed) & & .000 & .000 & .000 \\
\hline & $\mathrm{N}$ & 102 & 102 & 102 & 102 \\
\hline \multirow[t]{3}{*}{ KecemasanSosial } & $\begin{array}{l}\text { Pearson } \\
\text { Correlation }\end{array}$ & $.380^{* *}$ & 1 & .120 & $-.513^{* *}$ \\
\hline & Sig. (2-tailed) & .000 & & 228 & .000 \\
\hline & $\mathrm{N}$ & 102 & 102 & 102 & 102 \\
\hline \multirow[t]{3}{*}{ Materialisme } & $\begin{array}{l}\text { Pearson } \\
\text { Correlation }\end{array}$ & $.511^{* *}$ & .120 & 1 & $-.513^{* *}$ \\
\hline & Sig. (2-tailed) & .000 & .228 & & .000 \\
\hline & $\mathrm{N}$ & 102 & 102 & 102 & 102 \\
\hline \multirow[t]{3}{*}{$\begin{array}{l}\text { Subjective Well- } \\
\text { Being }\end{array}$} & $\begin{array}{l}\text { Pearson } \\
\text { Correlation }\end{array}$ & $-.429^{* *}$ & $-.513^{* *}$ & $-.513^{* *}$ & 1 \\
\hline & Sig. (2-tailed) & .000 & .000 & .000 & \\
\hline & $\mathrm{N}$ & 102 & 102 & 102 & 102 \\
\hline
\end{tabular}

**. Correlation is significant at the 0.01 level (2-tailed).

Berdasarkan hasil uji korelasi pearson tersebut dapat ditunjukkan bahwa koefisien regresi subjective well being sebesar $-0,429$ dengan signifikansi sebesar $0,000(p<0,05)$. Maka dapat disimpulkan bahwa terdapat hubungan yang signifikan negatif antara subjective well being dengan smartphone addiction. 
RAHMAH SANIATUZZULFA \& ALIFA NUR WIJAYANTI, Smartphone Addiction

Ditinjau dari Subjective Well Being, Kecemasan Sosial, dan Materialisme Pada Mahasiswa

Berdasarkan hasil tersebut dapat ditunjukkan pula bahwa korelasi pada variabel kecemasan sosial 0,380 dengan signifikansi sebesar 0,000 ( $\mathrm{p}<0,05)$. Maka dapat disimpulkan bahwa terdapat hubungan yang signifikan kecemasan sosial dengan smartphone addiction.

Berdasarkan hasil tersebut dapat ditunjukkan pula bahwa korelasi pada variabel materialisme 0,511 dengan signifikansi sebesar 0,000 ( $p<0,05)$. Maka dapat disimpulkan bahwa terdapat hubungan yang signifikan materialisme dengan smartphone addiction.

Berikut ini merupakan hasil kategoriasi variabel:

Tabel 4

Kriteria dan Kategorisasi Responden Penelitian

\begin{tabular}{|c|c|c|c|c|}
\hline \multirow{2}{*}{ Variabel } & \multicolumn{2}{|c|}{ Kategorisasi } & \multicolumn{2}{|c|}{ Komposisi } \\
\hline & Skor & Kategorisasi & Jumlah & Persentase \\
\hline $\begin{array}{l}\text { Smartphone } \\
\text { Addiction }\end{array}$ & $\begin{array}{c}24 \leq X<38,4 \\
38,4 \leq X<52,8 \\
52,8 \leq X<67,2 \\
67,2 \leq X<81,6 \\
81,6 \leq X<96\end{array}$ & $\begin{array}{l}\text { Sangat Rendah } \\
\text { Rendah } \\
\text { Sedang } \\
\text { Tinggi } \\
\text { Sangat Tinggi }\end{array}$ & $\begin{array}{c}- \\
14 \\
74 \\
13 \\
1\end{array}$ & $\begin{array}{c}13,7 \% \\
72,5 \% \\
12,7 \% \\
1 \%\end{array}$ \\
\hline Materialisme & $\begin{array}{c}21 \leq X<33,6 \\
33,6 \leq X<46,2 \\
46,2 \leq X<58,8 \\
58,8 \leq X<71,4 \\
71,4 \leq X<84\end{array}$ & $\begin{array}{l}\text { Sangat Rendah } \\
\text { Rendah } \\
\text { Sedang } \\
\text { Tinggi } \\
\text { Sangat Tinggi }\end{array}$ & $\begin{array}{c}52 \\
40 \\
5 \\
-\end{array}$ & $\begin{array}{c}4,9 \% \\
51 \% \\
39,2 \% \\
4,9 \%\end{array}$ \\
\hline $\begin{array}{l}\text { Subjective well- } \\
\text { being }\end{array}$ & $\begin{array}{c}26 \leq X<41,6 \\
41,6 \leq X<57,2 \\
57,2 \leq X<72,8 \\
72,8 \leq X<88,4 \\
88,4 \leq X<104\end{array}$ & $\begin{array}{l}\text { Sangat Rendah } \\
\text { Rendah } \\
\text { Sedang } \\
\text { Tinggi } \\
\text { Sangat Tinggi }\end{array}$ & $\begin{array}{c}- \\
1 \\
43 \\
55 \\
3\end{array}$ & $\begin{array}{c}1 \% \\
42,2 \% \\
53,9 \% \\
2,9 \%\end{array}$ \\
\hline
\end{tabular}

Kontribusi subjective well being, kecemasan sosial, dan materialisme secara bersamasama adalah 36,5\% dengan variabel subjective well being sebesar 1,67\%, variabel kecemasan sosial sebesar $11,59 \%$, sedangkan variabel materialisme sebesar $23,2 \%$.

Hasil pengujian hipotesis pada penelitian ini membuktikan bahwa hipotesis pertama yang sudah ditetapkan sebelumnya dalam penelitian ini dapat diterima, yakni terdapat hubungan antara subjective well being, kecemasan sosial, dan materialisme dengan smartphone addiction pada mahasiswa universitas "Y"

Hal tersebut ditunjukkan melalui beberapa hasil perhitungan seperti perhitungan nilai koefisien korelasi, $p$-value, dan besarnya $F_{\text {hitung. Hasil perhitungan diperoleh nilai koefisien }}$ korelasi sebesar $\mathrm{R}=0,604$ yang berarti adanya pengaruh yang sedang dari subjective well being, kecemasan sosial, dan materialisme dengan smartphone addiction. Kemudian $p$-value sebesar $0,000(p<0,05)$ dan nilai $F_{\text {hitung }}$ sebesar 18,757 yang berarti lebih besar dari $F_{\text {tabel }}$ sebesar 2,70. Berdasarkan beberapa perhitungan yang sudah dilakukan, dapat disimpulkan bahwa subjective well being, kecemasan sosial, dan materialisme secara bersama memiliki hubungan dengan smartphone addiction pada mahasiswa universitas " $Y$ ".

Hasil penelitian ini sejalan dengan penelitian yang telah dilakukan Lee, Chang, Lin, dan Cheng (2014), yakni beberapa faktor yang menjadi penyebab smartphone addiction antara lain external locus of control, materialisme, kecemasan sosial dan need for touch.

Subjective well being berkorelasi negatif dengan permasalahan smartphone addiction (Mahajan, Gupta, dan Bakhshi, 2017).. Ketika seseorang puas dengan kehidupannya, ia akan jauh dari permasalahan stress dan depresi. Berbeda dengan individu yang memiliki subjective 
well being rendah, ia akan menganggap kehidupannya sebagai sebuah peristiwa yang tidak menyenangkan sehingga muncul emosi yang tidak menyenangkan, seperti mudah merasa tertekan, stress, dan depresi (Diener, 1984). Ia akan lebih senang menyendiri dan memilih cara untuk menghilangkan stress nya tersebut dengan aktif menggunakan smartphone (Young, 2004). Semakin tinggi subjective well being, maka smartphone addiction semakin rendah. Begitu juga sebaliknya, semakin rendah subjective well being, maka semakin tinggi smartphone addiction.

Individu dengan kecemasan sosial menunjukkan kurangnya kepercayaan diri dalam bersosialisasi dengan lingkungan sehingga akan menghindari kontak sosial secara langsung. Ia lebih memilih berkomunikasi dengan menggunakan media chat karena merasa nyaman dan jauh dari intimidasi orang lain (Lee, Chang, Cheng \& Lin, 2016).

Selain itu, seseorang dengan materialisme tinggi menggunakan smartphone bukan hanya karena melihat kemudahan yang ditawarkan smartphone tersebut, melainkan karena nilai yang diberikan dari smartphone yang dimilikinya tersebut (Roberts \& Pirog, 2013; Roberts, Pullig, \& Manolis, 2015).

Berdasarkan paparan diatas, dapat diambil kesimpulan bahwa subjective well being, kecemasan sosial, dan materialisme secara simultan menjadi faktor yang dapat memengaruhi smartphone addiction.

Selain itu, hasil korelasi pearson antara subjective well being dengan smartphone addiction menunjukkan koefisien regresi variabel smartphone addiction sebesar -0,429 dengan nilai signifikansi 0,000 ( $p$ value $<0,05$ ). Hal ini dapat dikatakan bahwa variabel subjective well being berkontribusi signifkan negatif dengan variabel smartphone addiction.

Penelitian Lachmann, Sariyska, Kannen, Stavrou, \& Montag (2017) menjelaskan kepuasan hidup seseorang berkorelasi dengan internet addiction. Individu yang tidak puas dengan kehidupannya akan lebih memilih untuk menghabiskan waktunya dengan internet dan media sosial.

Hasil korelasi pearson antara kecemasan sosial dengan smartphone addiction menunjukkan koefisien regresi variabel iklim sekolah sebesar 0,380 dengan nilai signifikansi $0,000$ ( $p$ value $<0,05)$. Hal ini dapat dikatakan bahwa variabel kecemasan sosial memiliki kontribusi positif signifikan dengan variabel smartphone addiction.

Hasil penelitian ini sesuai dengan penelitian yang telah dilakukan Lee, Chang, Lin, dan Cheng (2014). Pengaruh kecemasan sosial terhadap adiksi telepon cerdas, dijelasakan telepon cerdas sebagai hal yang digunakan seseorang untuk bergantung atau mengurangi perasaan tidak nyaman ketika dalam melakukan kontak sosial. Spacz, Rockman, dan Clark (2015) menambahkan seseorang dengan kecemasan sosial merasakan nyaman untuk terus menjaga jarak sosial dengan berkomunikasi melalui telepon cerdas. Darcin, dkk (2016), menambahkan bahwa penggunaan telepon cerdas oleh seseorang dengan kecemasan sosial untuk menghindari hubungan atau kontak dengan orang lain dalam waktu yang sama.

Hasil korelasi pearson antara materialisme dengan smartphone addiction menunjukkan koefisien regresi variabel motivasi berprestasi sebesar 0,511 dengan nilai signifikasi 0,000 ( $p$ value $<0,05)$. Hal ini dapat dikatakan bahwa variabel materialisme berkontribusi positif signifikan dengan variabel smartphone addiction.

Hasil penelitian ini sesuai dengan penelitian yang telah dilakukan Lee, Chang, Lin, dan Cheng (2014), Roberts, Pullig, dan Manolis (2016), serta Roberts dan Pirog (2013). Peran materialisme yang dapat menyebabkan seseorang menjadi adiksi telepon cerdas, yaitu pada nilai yang diberikan orang tersebut terhadap telepon cerdas yang dimiliki sebagai barang yang dianggap penting (Lee, Chang, Lin,.dan Cheng, 2014). Roberts, Pullig, dan Manolis (2016), menjelaskan bahwa fungsi dan penampilan telepon cerdas bagi seseorang sekarang lebih dari 
RAHMAH SANIATUZZULFA \& ALIFA NUR WIJAYANTI, Smartphone Addiction

Ditinjau dari Subjective Well Being, Kecemasan Sosial, dan Materialisme Pada Mahasiswa

hanya sebagai barang yang bermanfaat. Roberts dan Pirog (2012), mengatakan bahwa telepon cerdas memberikan peran penting dalam kehidupan sosial seseorang dan sebagai simbol status terutama pada mahasiswa dan dewasa awal.

Sumbangan pengaruh yang diberikan subjective well being, kecemasan sosial, dan materialisme secara bersama-sama terhadap smartphone addiction yaitu sebesar $36,5 \%$, sisanya sebesar $63,5 \%$ merupakan pengaruh dari beberapa faktor lain seperti aplikasi yang sering dibuka, habit, leisure boredom, dan sebagainya. Adapun hasil sumbangan relatif variabel subjective well being sebesar 4,57\%, variabel kecemasan sosial sebesar 31,75\%, sedangkan variabel materialisme sebesar sebesar $63,56 \%$. Kemudian, untuk hasil sumbangan efektif variabel subjective well being sebesar $1,67 \%$, variabel kecemasan sosial sebesar $11,59 \%$, sedangkan variabel materialisme sebesar $23,2 \%$.

\section{KESIMPULAN}

Berdasarkan hasil penelitian yang diperoleh, maka dapat diambil beberapa kesimpulan terdapat hubungan signifikan antara subjective well being, kecemasan sosial, dan materialisme dengan smartphone addiction pada mahasiswa universitas "Y".

Berdasarkan hasil penelitian yang diperoleh, maka dapat dikemukakan beberapa saran antara lain bagi mahasiswa Universitas "Y" dalam kategori tingkat smartphone addiction sedang, sehingga diharapkan mampu menggunakan smartphone yang dimiliki dengan lebih bijak, diharapkan mampu meningkatkan kesadaran diri dalam menggunakan smartphone. Hal-hal yang dapat dilakukan antara lain tidak menggunakan smartphone saat berkumpul dengan keluarga atau teman, membuat kesepakatan bersama baik di keluarga ataupun di lingkungan sosial untuk tidak menggunakan smartphone, menambah kegiatan positif untuk mengisi waktu luang serta berusaha tidak menggunakan smartphone dan fokus pada kegiatan tersebut, berkomitmen untuk mendahulukan tugas atau aktivitas yang lebih penting, dan sebagainya.

Bagi pihak Universitas "Y" dapat memberikan tambahan pengetahuan kepada mahasiswa untuk memahami faktor yang menyebabkan smartphone addiction, seperti menyelenggarakan seminar ataupun membuat poster iklan yang ditempelkan pada majalah dinding setiap fakultas atau perpustakaan yang bertema penggunaan smartphone sewajarnya.

Bagi peneliti selanjutnya diharapkan dengan adanya penelitian ini dapat menjadikan masukan bagi peneliti selanjutnya untuk meneliti berbagai faktor smartphone addiction lainnya, seperti aplikasi yang sering dibuka, habit, leisure boredom, dsb.

\section{DAFTAR PUSTAKA}

Aljomaa, S. S., Al Qudah, M. F., Albursan, I. S., Bakhiet, S. F., \& Abduljabbar, A. S. (2016). Smartphone Addiction among University Students in the Light of Some Variables. Computers in Human Behavior, 61, 155-164. doi: 10.1016/j.chb.2016.03.041.

Cha, S. S. \& Seo, B. K. (2018). Smartphone Use and Smartphone Addiction in the Middle School Students in Korea: Prevalence, Social Networking Service, and Game Use. Health Psychology Open, 5, 1-15. doi: 10.1177/2055102918755046.

Darcin, A. E., Kose, S., Noyan, C. O., Nurmedov, S., Yilmaz, O., \& Dilbaz, N. (2016). Smartphone Addiction and Its Relationship with Social Anxiety and Loneliness. Behaviour \& Information Technology, 30, 505-510. doi: 10.1080/0144929X.2016.1158319.

Diener, E. (1984). Subjective Well Being. Psychological Bulletin. 1984. Vol 95

Diener, E., Oisho, S., dan Lucas, R.E. (2003). Personality, Culture, and Subjective Well Being: Emotional and Cognitive Evaluation of Life. Annual Reviews Psychology 54:403-25.

Kumalasari, F. \& Ahyani, L, N. (2012). Hubungan antara Dukungan Sosial dengan Penyesuaian Diri Remaja di Panti Asuhan. Jurnal Psikologi Pitutur. $\quad$ 1(1), 21-31

Kumcagiz, H., Gunduz, Y. (2016). Relationship between Psychological Well-Being and Smartphone Addiction of University Students. International Journal of Higher Education. Vol 5 No. 4 pg 144-156. 
Kwon, M., Lee, J. Y., Won, W. Y., Park, J. W., Min, J. A., Hahn, C., \& Kim, D. J. (2013a). Development and Validation of a Smartphone Addiction Scale (SAS). PloS One, 8, e56936. doi: 10.1371/journal.pone.005693.

Kwon, M., Kim, D. J., Cho, H., \& Yang, S. (2013b). The Smartphone Addiction Scale: Development and Validation of a Short Version for Adolescents. PloS ONE, 8, e83558. doi:10.1371/journal.pone.0083558.

Lachmann, B., Sariyska, R., Kannen, C., Stavrou, M., \& Montag, C. (2017). Commuting, LifeSatisfication, and Internet Addiction. International Journal of Environmental Research and Public Helath.

Lee, H., Ahn, H., Choi, S., Choi, W. (2014). The SAMS: Smartphone Addiction Management System and Verivication. J Med Syst, 38, 1-10. doi: 10.1007/s10916-013-0001-1.

Lee, Y. K., Chang, C. T., Lin, Y., \& Cheng, Z. H. (2014). The Dark Side of Smartphone Usage: Psychological Traits, Compulsive Behavior, and Technostress. Computers in Human Behavior, 31, 373-383. doi: 10.1016/j.chb.2013.10.047.

Lee, Y. K., Chang, C. T., Cheng, Z. H., \& Lin, Y. (2016). How Social Anxiety and Reduced Self-Efficacy Induce Smartphone Addiction in Materialistic People. Social Science Computer Review, 36, 36-56. doi: 10.1177/0894439316685540.

Mahajan, R., Gupta, R., \& Bakhshi, A. (2017). Personality, Loneliness, and Subjective WellBeing as Predictors of Problematic Mobil Phone Usage. International Journal of Applied Social Science. Vol. 4 pg 472-482.

Mattick, R. P., Clarke, J. C. (1998). Development and Validation of Measures of Social Phobia Scrunity Fear and Social Interaction Anxiety. Behaviour Research and Therapy, 36, 455-470. doi: 10.1016/s0005-7967(97)10031-6.

Roberts, J. A., Pullig, C., \& Manolis, C. (2015). I Need My Smatphone: A Hierarchical Model oF Personality and Cell-Phone Addiction. Personality and Individual Differences, 79, 13-19. doi: 10.1016/j.paid.2015.01.049.

Richins, M. L. (2004). The Material Values Scale: Measurement Properties and Development of a Short Form. Journal of Consumer Research, 31, 209-219. doi: 10.1086/383436.

Richins, M. L., \& Dawson, S. (1992). A Consumer Values Orientation for Materialism and Its Measurement: Scale Development and Validation. Journal of Consumer Research, 19, 303-316.

Roberts, J. A. \& Pirog, S. F. (2013). A Preliminaary Investigation of Materialism and Impulsiveness as Predictors of Technological Addictions among Young Adults. Journal of Behavioral Addictions, 2, 56-62. doi: 10.1556/JBA.1.2012.011.

Samaha, M. \& Hawi, N. Z. (2016). Relationship among Smartphone Addiction, Stress, Academic Performance, and Satisfaction with Life. Computers in Human Behaviour, 57, 321-325. doi: 10.1016/j.chb.2015.12.045.

Spacz, M., Rockman, G., Clark, J. (2016). Are We Addicted to Our Cell Phones?. Computers in Human Behavior, 57, 153-159. doi: 10.1016/j.chb.2015.12.004.

Yao, M. Z. \& Zhong, Z. J. (2014). Loneliness, Social Contacts and Internet Addiction: A CrossLagged Panel Study. Computers in Human Behavior, 30, 164-170. doi: 10.1016/j.chb.2013.08.007.

Young, K. (2004). Internet Addiction: A New Clinical Phenomenon and Its Consequences. American Behavioral Scientist. 48(2), 402-415

Yuwanto, L. (2010). Mobile Phone Addict. Surabaya: Putra Media Nusantara. 